\title{
A research note of potential scientific management accounting research area in CEECs
}

\author{
Beata Zyznarska-Dworczak ${ }^{\mathrm{al}}$ \\ a Poznan University of Economics and Business, Poland
}

\begin{abstract}
A bstract: The paper is a commentary on the future of management accounting in Central and Eastern European countries, portrayed in the manuscript in the J ournal Sustainability in its Special Issue titled "Corporate Social Responsibility (CSR) in Developing Countries: Current Trends and Development". The manuscript "The Development Perspectives of Sustainable Management Accounting in Central and Eastern European Countries" written by Beata Zyznarska-Dworczak promotes the role of management accounting in a wider social, ethical, environmental, cultural and historical context. This approach contributes to the understanding of sustainable management accounting towards socio-economic transformations and developments in Central and Eastern European countries, in the research perspectives of alternative management accounting. It encourages to treat sustainable management accounting as a social and institutional activity, real izing a complementary role (to conventional) of the management accounting system in this region of Europe because of its emerging economy perspective. This approach determines new potential scientific management accounting research area. The aim of this paper is to outline the potential for researchers to influence the development perspectives of sustainable management accounting. The paper, as a thought provoking discussion of science, raises the following questions: may the alternative context of sustainable management accounting provide opportunities for researchers investigating accounting issues in Central and Eastern European countries? is it possible to combine alternative perspectives into management accounting research? how to combine it with conventional economics-based mainstream research? How to measure corporate sustainability performance in management accounting system?
\end{abstract}

\footnotetext{
${ }^{1}$ Corresponding author: Department of Accounting, Poznan University of Economics and Business; Al. Niepodległości 10, 61-875 Poznan; tel. (+48) 6185 43 833; email address: b.zyznarska-dworczak@uepoznan.pl.
} 
K eywords: accounting theory, corporate social responsibility, management accounting, Central and Eastern European countries, CEECs, discussion

J EL codes: M41, M42, M49.

\section{Introduction}

Management accounting research is usually carried out using a conventional, mainstream approach, characterized by functionalism and rationalism. An alternative approach to management accounting, in tum, entails expanding the basis on which management accounting is conceptual ized. It demonstrates the role of accounting in a wider social, ethical, environmental, cultural and historical context. Such approach expands the scope of management accounting research to include, among other things, the theories of organization, sociology, psychology and philosophy, as well as behavioral theories. Thus, creates the basis for scientific understanding of the impact of sustainability on management accounting area, in a different context.

The paper is a commentary on the future of management accounting in Central and Eastern European countries (CEECS), portrayed in the manuscript in the Joumal Sustainability in its Special Issue titted "Corporate Social Responsibility (CSR) in Developing Countries: Current Trends and Development". The manuscript "The Development Perspectives of Sustainable Management Accounting in Central and Eastern European Countries" (Zyznarska-Dworczak, 2018) (in the further part of this paper it is named "Manuscript") contributes to the understanding of sustainable management accounting in the context of socio-economic transformations and developments in Central and Eastern European countries, in the research perspectives of altemative management accounting. It promotes to treat sustai nable management accounting (SMA) as a social and institutional activity, realizing a complementary role (to conventional) of the management accounting system Such approach is dedicated for CEECs because of its emerging economy perspective and specific features of the market.

An alternative approach to SMA determines new potential scientific management accounting research area. So the aim of this paper is to outline the potential for researchers to influence the development perspectives of sustainable management accounting. The paper as a thought provoking discussion of science raises the following questions:

- May the alternative context of sustainable management accounting provide opportunities for researchers investigating accounting issues in Central and Eastern European countries? 
- Is it possible to combine alternative perspectives into management accounting research?

- How to combine alternative approach into management accounting research with conventional economics-based mainstream research?

- How to measure corporate sustainability performance in management accounting system?

So the aim of this paper is to outdine the potential for researchers to influence the development perspectives of sustainable management accounting in CEECs in the light of al ternative management accounting research, promoted in the Manuscript.

\section{The development of management accounting in CEEC S}

The features of the current business environment shape the characteristics of management accounting practices used in business (Albu \& Albu, 2012: 245). However, there are many factors directing management accounting practices toward convergence or divergence around the world (f.e. Granlund \& Lukka, 1998; Zarzycka et al., 2017). This is the subject of numerous studies in the form of comparative international, comparative cross-national or inter-industry longitudinal studies (Mia \& Chenhall, 1994; Libby \& Waterhouse, 1996; Chenhall \& LangfieldSmith, 1998a; Chenhall \& Langfield-Smith, 1998b; Granlund \& Lukka, 1998; Simionescu \& Bica, 2016; Ax \& Greve, 2017; Pratheepkanth, 2018). Although the growth in international managerial accounting research over the last decades has been significant, there are no general frameworks to help researchers identify opportunities to add to this body of knowledge (Haka \& Heitger, 2004: 21). The cause of this phenomenon can be seen in the relative perception of economic, social and environmental corporate responsibilities in different region of the world.

An innovative approach to management accounting in Central and Eastem European Countries, adopting "alternative" theoretical and methodological perspectives promotes the manuscript "The Development Perspectives of Sustainable Management Accounting in Central and Eastern European Countries", written by Zyznarska-Dworczak (2018), issued in Journal Sustainability in its Special Issue titled "Corporate Social Responsibility (CSR) in Developing Countries: Current Trends and Development". The innovative nature of promoted in the manuscript approach is proved by the means of bibliometric analysis, based on the database of the scientific papers in the Web of Science' database relating to management accounting research in CEECs from 1945-2017 (ZyznarskaDworczak 2018: 3-8). A bibliometric data indicate that the number of publications relating to management accounting research in Central and Eastern European countries is low, but it shows growth over the analyzed period. Over than $72 \%$ of publication comes from 3 countries: Romania (57\%), Czech Republic (38\%) and Poland (23\%). Additionally, most publications come from the second decade of the 21 st century, and over $50 \%$ from the last 4 years. This study reveals key trends in 
changes in the field of management accounting research, and al lows to anticipate the direction of future research in this region.

The Manuscript of Zyznarska-Dworczak assumes that Central and Eastern European countries may be treated as a homogeneous research group for implicating the development perspectives of management accounting because of their historical, cultural, social, institutional and economic circumstances differing between these countries and more developed region. So the key factors influencing management accounting devel opment in CEECs result from (Zyznarska-Dworczak, 2018: 8):

- socio-economic transformations and developments;

- globalization and gl obal competition;

- limited resources: capital assets, human resources (including management), intel lectual capital, IT, new technology;

- facing financial crises with weaker financial and operational facilities than the rich West,

- increasingly strong corporate relationships with companies from Western Europe, necessitating the implementation of international policies by subsidiaries,

- looking for the solutions to strengthen their management systems which will be capable of reacting to the changing internal and external environment;

- a growing need for the transformation of the sustainability of organizational practices.

Due to Zyznarska-Dworczak (2018) management accounting development is al so determined by the need of meeting the stakeholders' expectations regarding credibility and transparency in corporate reporting, their CSR involvement, and thus gaining a comparative advantage that encourages the market to cooperate and the capital to invest. The observed in the companies from CEECs changes concern organizational structure, their production structure, managerial practices taking into account the social, environmental and ethical expectations, performance measurement, demand for more detailed information about their socio-economic and environmental potential, the need for better skills and competency of accountants (Zyznarska-Dworczak, 2018: 8).

Nevertheless the constraints of CEECS, like education, quality, know-how, technology, IT, acquisition of knowledge in the area of management accounting by enterprises in CEECs, may make management accountants to concentrate on corporate economic goals and limit their responsibility for their socioenvironmental performance.

Notwithstanding, sustainability is a concept that has gained increased attention among social and economic actors in recent years, and also determines the 
management accounting perspectives. CSR-related matters in CEECs has become "an important concept materializing in the accounting academic and practitioner literature, as well as in the practices of local companies" (Albu et al., 2016: 193). And though management accounting research is usually carried out using a conventional, mainstream approach, Zyznarska-Dworczak (2018) proves in her Manuscript that the analysis of the prospects of the development of management accounting in CEECs requires the perception of the role of management accounting in a wider social, ethical, environmental, cultural and historical context (thesis no 1 of the Manuscript).

This approach enabled Zyznarska-Dworczak to state that alternative scientific research drives the development of management accounting towards social practice, determined by the nature of the organizational and social environment, laying the foundations for an analysis of the development of sustainable management accounting in CEECs (thesis no 2 of the Manuscript). In the next stage it is proved that sustai nable management accounting as a social practice can be a subject of al ternative scientific research in the area of management accounting (thesis no 3 of the Manuscript). As the main conclusions the Manuscript indicates the proof of the thesis no. 4 that sustai nable management accounting as a subject of al ternative scientific management accounting research may constitute a means of promoting management accounting research in CEECs' companies (Zyznarska Dworczak, 2018: 2). The Manuscript is an attempt of theoretical and methodological proving of these statements.

\section{An alternative approach to SM A as potential scientific management accounting research area}

Conventional research is considered to be dominant in management accounting research (Chua, 1988; Baker 1997; Baxter \& Chua, 2003; Baxter \& Boedker 2008; Wanderley \& Cullen 2011). Such research results in positive theories, used for the explanation of the rules, meanings, and development of certain management accounting concepts (Hoque, 2006: 3). Notwithstanding, the mainstream type of management accounting research has been criticized by various researchers (eg., Scapens, 1994; Wickramasinghe \& Alawattage, 2012; Williams, 2014; Hopper \& Bui, 2016; Alawattage et al., 2017), who have identified serious problems in terms of developing knowledge and innovation in the research area. For these researchers, the simplification and reduction of reality via its quantification, and the formulation of hypotheses, have not contributed to a better understanding of management accounting and to predicting its development (Major 2017: 174).

In contrast to the "mainstream" paradigm, which has flourished and is still considered as the only credible research method in North America, altemative accounting research has found fertile ground in the UK, Australia, New Zeal and and Europe. Critical management accounting research is equipped with tools to 
challenge the claims of absolute truth and offer opportunities for informed and democratic debate (Alawattage et al., 2017: 178, 185). Assuming that accounting change is not linear, predictable, controllable, exclusively technical or wellbehaved (Baxter \& Chua, 2003: 107), some researchers adopt "alternative" perspectives in their research (c.f. Chua, 1988; Baker 1997; Lillis \& Mundy, 2005; Anderson \& Widener, 2006; Baxter \& Boedker, 2008; Wanderley \& Cullen, 2011; Major 2017; Alawattage et al., 2017; Zyznarska-Dworczak 2015, 2018). For alternative researchers, it is impossible to quantify and reduce reality, in contrast to what positivists believe (Major 2017: 174). One of the main objectives of alternative management accounting research is to treat it as a social practice, which is built by a mutual influence of the external and internal environment of a business enterprise It is pursued across scientific perspectives (Zyznarska Dworczak, 2018: 9).

The Manuscript promotes an adoption of alternative approach to management accounting in CEECs. Considering the conditions of management accounting development in CEECs, outlined in Part 2 of this article, the Manuscript postulates the theoretical framework of sustainable management accounting, from the emerging economy perspective conducted in the light of al ternative management accounting research. The Manuscript promote to treat SMA as a social and organizational activity, based on an internal accountability tool. SMA research may help to create the theoretical framework of sustainability control and planning system focused on the environment of a business entity and its environmental, social and ethical impact In this sense SMA is distinguished by its key features, like(Zyznarska-Dworczak 2018: 13-14):

- Focus on the environment of a business entity and its environmental, social and ethical impact;

- Balance between the economic, social, environmental and ethical goals;

- Basical ly internal perspective, supporting sustainability reporting al so external;

- Flexibility in defining corporate goals;

- An integrated form of planning and control methods for the fulfillment of economic, social and environmental goals supporting the evaluation of the business entity's impact on its environment;

- Dedicated instruments: Activity Based Responsibility Accounting, Sustainable BSC, Activity- and Strategy-Based Responsibility Accounting;

- Financial and non-financial indicators: economic, environmental (natural environmental), labor, social engagement, other;

- Long-term planning, control, motivating operating level personnel from the perspective of economic, environmental, social and ethical goals;

- Group decision-making, including lower level personnel, making it possible to take mul tiple business impact perspectives into account 
The Manuscript proves that the anticipated direction of development of SMA research in CEECs may be analysed in each perspectives of alternative management accounting research, identified by Baxter and Chua (Baxter \& Chua, 2003):

1. institutional theory;

2. a non-rational design school;

3. naturalistic research;

4. the radical alternative;

5. structuration theory;

6. a Foucaul dian approach;

7. a Latourian approach.

As the results of the Manuscript indicate the greatest impact on SMA research in CEECs may have institutional theory, developed under the influence of the concept of institutionalism in sociology and the theory of organization. The institutional theory has become one of the most popular choices among management accounting researchers who seek to study management accounting change (Alsharari et al., 2015: 478). According to Scapens (1994) the institutional framework views accounting practices as institutionalized routines, which enable entities to reproduce and legitimate behaviour, and to achieve organizational cohesion. Moreover accounting as institutionalized routine creates understandings of activities according to particular sets of accounting rules and procedures which enable decisions to be made and activities undertaken in a complex and uncertain world (Scapens 1994: 301). Thus institutional theory's perspective may help to answer the management accounting research questions: how to understand the social and organizational nature of SMA? how to implement and evaluate an integrated form of tools? (table 1).

Table 1. SMA research question from institutional theory's perspective

\begin{tabular}{|l|l|}
\hline $\begin{array}{l}\text { Institutional } \\
\text { theory }\end{array}$ & $\begin{array}{l}\text { How to understand the social and organizational nature of SMA? } \\
\text { How to legitimateSMA? } \\
\text { How to implement and evaluate an integrated form of tools to } \\
\text { measure and bal ance the economic, social, environmental and ethical } \\
\text { goals? }\end{array}$ \\
\hline
\end{tabular}

(Source: Own elaboration based on Zyznarska-Dworczak, 2018: 12).

Institutional theory, assuming limited rationality and opportunism, may encourage accounting researchers to look seriously at the nature of all management accounting practices, and not to dismiss those practices which do not conform to some theoretical ideal (Scapens 1994: 301). In this way it helps to understand the social nature of the management accounting practice and to clarify the scope of various internal and external influences on development of management accounting systems. Thus, its perspective may be helpful in selection, implementation and evaluation of the methods used to measure and balance the 
economic, social, environmental and ethical goals. Harmonization of different objectives in a socially-responsible entity may also be researched in the light of a non-rational design school (table 2).

Table 2. SMA research question from a non-rational design school's perspective

\begin{tabular}{|c|c|}
\hline $\begin{array}{c}\text { A non- } \\
\text { rational } \\
\text { design school }\end{array}$ & $\begin{array}{l}\text { How to legitimate a seemingly irrational approach for business - not } \\
\text { only economically? } \\
\text { How to hamonize economic, environmental, social and ethical } \\
\text { objectives? and for how to plan it? } \\
\text { How to focus on the environment of a business entity and its } \\
\text { environmental, social and ethical impact? }\end{array}$ \\
\hline
\end{tabular}

(Source: Own elaboration based on Zyznarska-Dworczak, 2018: 12).

Since a non-rational design school questions presumptions of rationality in organizational choice, it helps to appreciate the problematic construction of management accounting information systems and their constitutive role in organisational sense-making. (Baxter, Chua, 2003: 98-99). Thus that approach may quite distinct from ideas about the sensible al location of resources that underscores other accounts of management accounting information systems and their use thanks to this it helps to legitimate a seemingly irrational approach for business, based not only on economic results but also on social and environmental achievements. In this sense SMA is expected to support corporate decisions targeted at the change from a rational maximization of business value/profit to the harmonization of goals.

Naturalistic research's perspective may, in tum, justifies management accounting research within specific organizational context It is enacted quite differently from one organisation to another, conveying local values, meanings and nuances (Baxter, Chua, 2003: 99). This school expands management accounting research perspectives and encourages to search for answers to the research questions presented in the table 3.

Table 3. SM A research question from naturalistic research's perspective

\begin{tabular}{|c|l|}
\hline $\begin{array}{c}\text { Naturalistic } \\
\text { research }\end{array}$ & $\begin{array}{l}\text { How to develop SMA against many financial and non-financial } \\
\text { factors influencing an entity performance? } \\
\text { How to eval uate the achieved by an entity performance influenced } \\
\text { by the complexities of its environment? } \\
\text { How to reevaluate these achievements against the changing internal } \\
\text { and external environment? }\end{array}$ \\
\hline \multicolumn{2}{|c|}{ (Source: Own elaboration based on Zyznarska-Dworczak, 2018: 12) }
\end{tabular}

It is worth investigating, how to develop SMA against many financial and nonfinancial factors influencing an entity performance It is also future direction of management accounting development research of searching for the answer to the question, how to eval uate and reevaluate corporate achievements influenced by the 
complexities of its environment This approach assumes that management accounting practices are influenced by the complexities of the multiple constructions of the environment and the expectations that they convey (Zyznarska-Dworczak 2018: 9). Thus, it also may be treated as an instrument to reduce the inequalities in an entity through proper capital allocation and performance management. It may be a key assumption of the radical al ternative in management accounting research (table 4).

Table 4. SM A research question from the radical alternative's perspective

\begin{tabular}{|c|l|}
\hline $\begin{array}{c}\text { The radical } \\
\text { al ternative }\end{array}$ & $\begin{array}{l}\text { How to reduce the inequalities in an entity through proper capital } \\
\text { allocation and performance management? } \\
\text { May SMA help to reduce the inequalities? How to manage it? }\end{array}$ \\
\hline
\end{tabular}

(Source: Own elaboration based on Zyznarska-Dworczak, 2018: 12)

The radical alternative is the answer to facts that inequality undermines corporate social stability and that members of organisations and society internalise values that reproduce an unequal society (Baxter \& Chua, 2003: 99). In this school SMA research is expected to reduce the inequalities in an entity through proper capital al location and performance management The implementation of this task requires development of an integrated form of planning and control methods and tools for the fulfillment of economic, social and environmental goals supporting their harmonization. Such research may derive its strength from a combination of quantitative and qual itative research methods, since they require the integration of quantitative and qualitative data from various perspectives of business (ZyznarskaDworczak, 2018: 15).

The understanding of accounting as a social and organizational practice may also be explained according to the assumption of structuration theory. As is presented in table 4, this alternative approach may support researchers in interpreting the connection of management accounting with institutionalized social relationships (Zyznarska-Dworczak, 2018: 13).

Table 5. SM A research question from structuration theory's perspective

\begin{tabular}{|c|l|}
\hline $\begin{array}{c}\text { Structuration } \\
\text { theory }\end{array}$ & $\begin{array}{l}\text { How to interpret the connection of management accounting with } \\
\text { institutionalized social relationships? } \\
\text { How to support the understanding of accounting as a social and } \\
\text { organizational practice? } \\
\text { How to legitimateSMA as a way of goals communication? }\end{array}$ \\
\hline
\end{tabular}

(Source: Own elaboration based on Zyznarska-Dworczak, 2018: 12).

Structuration theory relates to the process of conceptualizing the interconnection between the agency of individuals and the reproduction of social structures, it assigns an equal importance to the structure and the agency, and is intended to 
show how management accounting is connected with institutionalized social relationships (Baxter, Chua, 2003: 99).

A Foucaul dian approach, using organization and management theories, is dedicated to research into team coordination and flexibility of defining goals. It suggests a means of motivating management accounting to become actively involved in business responsibility, and may be used for internal management decisionmaking, including financial and nonfinancial transactions that affect the external and internal environment of the business (Zyznarska-Dworczak 2018: 16). This approach is expected to find the answers to the research question: how to consider all the manifestations of power relations in a socially-responsible entity, expected to harmonize its different goals (table 6).

Table 6. SM A research question from a Foucauldian approach's perspective

\begin{tabular}{|c|l|}
\hline $\begin{array}{c}\text { A } \\
\text { approach }\end{array}$ & $\begin{array}{l}\text { How to consider all the manifestations of power relations from the } \\
\text { perspective of the goals harmonization in a socially-responsibleentity? } \\
\text { How to motivate management accounting to become actively involved } \\
\text { in business sustainability and responsi bility? }\end{array}$ \\
\hline
\end{tabular}

(Source: Own elaboration based on Zyznarska-Dworczak, 2018: 12)

As the results of the Manuscript indicate this approach may also give rise to research on the possibilities of motivating management accounting to become actively involved in business sustainability. However, this research area requires in-depth investigation relating the coordination of an entity's team in achieving the harmonization of the goals. A complement to the answer to this research question may be a response given by a Latourian approach, which may help to research the role of management function in the harmonization of economic, environmental, social and ethical goals (Zyznarska-Dworczak, 2018: 13). A Latourian approach, which uses sociological actor-network theory, allows to understand the relationships of the parties-users accounting system from the perspective of the pursuit of their own goals (table 7).

Table 7. SM A research question from a $L$ atourian approach's perspective

\begin{tabular}{|c|l|}
\hline $\begin{array}{c}\text { A Latourian } \\
\text { approach }\end{array}$ & $\begin{array}{l}\text { How to coordinate an entity's team in achieving the harmonization of } \\
\text { the goals? }\end{array}$ \\
$\begin{array}{l}\text { How to definethe goals in flexible way? } \\
\text { economic, environmental, social and ethical goals? }\end{array}$
\end{tabular}

(Source: Own elaboration based on Zyznarska-Dworczak, 2018: 12)

Adopting an Latourian approach in management accounting research may support to understand stakehol ders' information needs, and determine what kind of data the SMA should provide, and thus, the direction in which the management is supposed 
to act. The Latourian approach perspective may significantly assist management accounting researchers in the application of SMA to motivate personnel across the organization to respect social responsibility policy objectives, including sociological techniques. (Zyznarska-Dworczak 2018: 13, 16).

As the findings of the Manuscript, presented in Tables 2-7, indicate that the concept of SMA research requires a consideration of the widest relationships of an entity to its environment, and its impacts in the longest period possible when measuring achievements. Therefore, the author's concept focuses on interpretative and critical research requiring an expansion of the current quantitative research, so that it includes qualitative research. It allows the inclusion of non-financial information in the management accounting system, which is generally skipped in the mainstream approach. As emphasized in the Manuscript valuable area of management accounting research is the phenomenon of how an organizational and social context moves management accounting systems towards the cognitive and cultural explanations of an entity. At the same time it is worth examining how these aspects empower the management accounting system to perform stabilizing and standardizing functions within an entity in CEECs (Zyznarska-Dworczak, 2018: 15). Although the development perspectives of management accounting in Central and Eastern European countries is extensively influenced by corporate goals and social needs resulting primarily from political, structural, social and economic transformations in this region, there is still place for scientific solutions, useful for both theory and practice.

\section{Conclusions}

The paper presents a multi-dimensional picture of the complexity and variety of sustainability management accounting in Central and Eastern European countries, promoted in the Manuscript of Zyznarska-Dworczak (2018). This approach postulates the understanding of changes and the prospects for the devel opment of management accounting in this region, with in-depth consideration of corporate sustainability by perceiving the role of accounting in a wider social, ethical, environmental, cultural and historical context. The paper proves that each of the al temative approaches to management accounting research determines the potential of future research of sustai nable management accounting in CEECs. The paper, as a thought provoking discussion of science, raises many research questions relating the direction of future research in this region. 


\section{R eferences}

Alawattage, C. G., Wickramasinghe, D., Tsamenyi, M., \& Uddin, S. (2017) “Doing critical management accounting research in emerging economies", Advances in Scientific and Applied Accounting: 177-188.

Albu, N. \& Albu, C.N. (2012) "Factors associated with the adoption and use of management accounting techniques in developing countries: The case of Romania", J ournal of International Financial Management \& Accounting, 23(3): 245-276, doi:10.1111/jifm 12002.

Albu, C. N., Balsari, Ç \& Krasodomska, J. (2016) "Introduction to the Special Issue on Corporate Social Reporting in Central and Eastern Europe", Accounting and Management I nformation Systems, vol. 15, no. 2: 193-205.

Alsharari, N. M., Dixon, R. \& Youssef, M. A. E. A. (2015) “Management accounting change: critical review and a new contextual framework", J ournal of Accounting \& Organizational Change, 11(4): 476-502.

Anderson, S.W. \& Widener, S.K. (2006) "Doing quantitative field research in management accounting", in: Handbooks of Management Accounting Research, Chapman, C.S., Hopwood, A.G., Shields, M.D. (Eds), Elsevier: Oxford, UK, Vol. 1: 319-341.

Ax, C. \& Greve, J. (2017) "Adoption of management accounting innovations: Organizational culture compatibility and perceived outcomes", Management Accounting Research, 34: 59-74.

Baker, C.R. \& Bettner, M.S. (1997) "Interpretive and critical research in accounting: A commentary on its absence from mainstream accounting research", Critical Perspectives on Accounting, Vol. 8: 293-310, doi:10.1006/cpac.1996.0116.

Baxter, J.; Boedker, C. (2008), "The future(s) of interpretive accounting research A polyphonic response from beyond the metropolis", Critical Perspectives on Accounting, Vol. 19: 880-886, doi:10.1016/j.cpa.2007.02.009.

Baxter, J. \& Chua, W.F. (2003) "Alternative management accounting research Whence and whither", Accounting Organizations and Sociey, Vol. 28: 97-126, doi:10.1016/S0361-3682(02)00022-3.

Chenhall, R. H., \& Langfield-Smith, K. (1998a) "The relationship between strategic priorities, management techniques and management accounting: an empirical investigation using a systems approach", Accounting, Organizations and Society, Vol. 23(3): 243-264.

Chenhall, R., \& Langfield-Smith, K. (1998b) "Factors influencing the role of management accounting in the development of performance measures within organizational change programs", Management Accounting Research, Vol. 9(4): 361-386.

Chow, C. W., Kato, Y., \& Shields, M. D. (1994), "National culture and the preference for management controls: An exploratory study of the firm Labor market interface", Accounting, Organizations and Society, 19(4-5): 381-400. 
Chua, W.F. (1988) "Interpretive sociology and management accounting research A critical review", Accounting, Auditing and Accountability J ournal, Vol. 1: 59-79, doi:10.1108/EUM0000000004624.

Fijałkowska, J.; Zyznarska-Dworczak, B. \& Garsztka, P. (2017) "The relation between the CSR and the accounting information system data in Central and Eastern European (CEE) countries-the evidence of the Polish financial institutions", J ournal of Accounting and Management Information Systems, Vol. 16: 490-521.

Granlund, M., \& Lukka, K. (1998) "It's a small world of management accounting practices", J ournal of management accounting research, Vol. 10, 153.

Haka, S. F., Heitger, D. L. (2004), "International managerial accounting research: A contracting framework and opportunities", The International J ournal of Accounting, Vol. 39(1): 21-69.

Hopper, T. \& Bui, B. (2016) "Has management accounting research been critical?", Management Accounting Research, Vol. 31: 10-30, doi:10.1016/j.mar.2015.08.001.

Hoque, Z. (2006) "Introduction". In: Methodological Issues in Accounting Research: Theories, Methods and Issues, Hoque, Z. (Ed.), Spiramus Press Ltd.: London, UK.

Libby, T., \& Waterhouse, J. H. (1996) "Predicting change in management accounting systems", J ournal of management accounting research, Vol. 8, 137.

Lillis, A.M. \& Mundy, J. (2005) "Cross-sectional field studies in management accounting research - Closing the gaps between surveys and case studies", J ournal Management Accounting Research, Vol.17: 119-141.

Major, M.J. (2017) "Positivism and "alternative" accounting research", Revista Contabilidade \& Finanças, Vol. 28: 173-178, doi:10.1590/1808057x201790190.

Mia, L., \& Chenhall, R. H. (1994) "The usefulness of management accounting systems, functional differentiation and managerial effectiveness", Accounting, Organizations and Society, Vol. 19(1): 1-13.

Pratheepkanth, P. (2018) "Management Accounting Revolution: Developed and Developing Country", International J ournal of Economics and Management Engineering, Vol. 5(3).

Scapens, R.W. (1994) "Never mind the gap: Towards an institutional perspective on management accounting practice", Management Accounting Research, 5, 301-321, doi:10.1006/mare.1994.1019.

Simionescu, S., \& Bica, E. (2016) "Influence Factors Social and Cultural Rights on the Evolution of Management Accounting", J ournal of Advanced Research in Management, Vol. 7(2), 96.

Wanderley, C.; Cullen, J. (2011) "Management accounting research: Mainstream versus al ternative approaches", Contabilidade Vista and Revista, 22, 15-44.

Wickramasinghe, D., \& Alawattage, C. (2012) Management accounting change: approaches and perspectives. Routledge. 
Williams, P.F. (2014) "The myth of rigorous accounting research", Accounting Horizons, Vol. 28: 869-887, doi:10.2308/acch-50880.

Zarzycka, E., Dobroszek, J., Circa, C., \& Almasan, A. (2017), "The perceived suitability of management accounting information: a contingency based investigation", The Audit Financiar J ournal, 15(147): 395-395.

Zyznarska-Dworczak, B. (2015) „Zrównoważone zarządzanie kosztami wobec alternatywnych badań naukowych w rachunkowości zarządczej", Prace Naukowe Uniwersytetu Ekonomicznego we Wrocławiu, No. 398: 500-508, doi:10.15611/pn.2015.398.47.

Zyznarska-Dworczak, B. (2018) "The Development Perspectives of Sustainable Management Accounting in Central and Eastern European Countries", Sustainability, 10, 1445, doi:10.3390/su10051445. 